\title{
ANALYSIS OF VALUE CREATED PRODUCT STRATEGIES ON IMPROVING BUSINESS COMPETITIVENESS
}

\author{
Banuara Nadeak ${ }^{1}$, Reminta Lumban batu ${ }^{2 *}$ \\ 1,2Universitas Singaperbangsa Karawang, Indonesia \\ *Corresponding author: reminta.lumban@fe.unsika.ac.id
}

\begin{abstract}
The condition of Karawang as a national rice barn has now shifted to industrialization and supporting cities for the Capital City and has received poor ratings because it is a city with a high ranking of poor people. These problems can be solved by increasing MSME activities in various fields. The sustainability of MSME is very important because it supports the growth of big business and is able to provide benefits for regional economic growth. Implementation of value creation strategies in an effort to improve business activities carried out as a strategy at the corporate and business level. The application of value creation that focuses on internal resources owned is also related to the competitiveness strategy in an effort to increase the competitiveness of a company or a business. The purpose of this study was to determine how much influence the value creation product strategy has on increasing business competitiveness as an effort to improve the economy of poor families. This study uses descriptive and verification research methods, the method used is an explanatory survey. Data analysis technique used to determine the correlative relationship in this study is multiple regression using SPSS software. The results of this study indicate that there is a positive influence on a product strategy of value creation to increase business competitiveness and its impact on improving the economy of poor families.
\end{abstract}

Keywords: Value creation; Product strategy; Competitiveness; poor society

Received June ${ }^{9 t h} 2020 \quad$ Revision June ${ }^{29 \text { th }} 2020 \quad$ Accepted for Publication July ${ }^{14 \text { th }} 2020$

\section{INTRODUCTION}

Karawang, which is known as one of the food production centers that is able to meet rice needs, not only at the provincial level, even at the national level, there are still many people who find it difficult to buy rice, this is in contrast to the title carried by Karawang Regency as a Rice Granary which has shifted to Industrialization and the supporting city of the Capital. Based on data from the Central Statistics Agency (BPS) of Karawang Regency in 2017, 236,840 people or 10.25 percent of the Karawang population are categorized as poor. This number has not decreased since the last five years. In 2013 the poverty rate reached 238,573 or 10.69 percent, in 2014 it was 228,990 or 10.15 percent, in 
2015 it was 235,030 or 10.37 percent, in 2016 it was 230,600 or 10.07 percent and in 2017 it increased to 236,480 or 10.25 percent (merdeka.com, n.d.).

These problems can be resolved by increasing the activities of MSMEs in various fields. The sustainability of MSMEs is very important because it supports the growth of large businesses and is able to provide benefits for regional economic growth (Gilmore, 2011). MSMEs are always looking for ways to survive, grow and compete in the market (Valkokari \& Helander, 2007). The competitiveness of MSMEs in a country also affects the position of that country's MSMEs for international countries. Research in several countries, such as Italy, Palestine and Tanzania, shows that MSMEs are still experiencing problems with low competitiveness (Crick, Kaganda, \& Matlay, 2011; Sultan, 2014). This problem occurs in Indonesian MSMEs (Najib \& Kiminami, 2011; Tambunan, 2011).

Table 1

\section{Number of UMKM Units and Large Industry in Indonesia}

\begin{tabular}{cccccccc}
\hline No & $\begin{array}{c}\text { Scale } \\
\text { enterprises }\end{array}$ & 2010 & 2011 & 2012 & 2013 & 2014 & Total \\
\hline 1 & Usaha & $84,452,022$ & $87,810,366$ & $90,012,694$ & $93,014,759$ & $94,957,797$ & $450,247,638$ \\
& Mikro & & & & & & \\
2 & Usaha & $3,278,793$ & $3,519,843$ & $3,521,073$ & $3,627,164$ & $3,919,992$ & $17,866,865$ \\
& Kecil & & & & & & \\
3 & Usaha & $2,761,135$ & $2,694,069$ & $2,677,565$ & $2,759,852$ & $2,844,669$ & $13,737,290$ \\
& Menengah & & & & & & \\
4 & UMKM & $90,491,950$ & $94,024,278$ & $96,211,332$ & $99,401,775$ & $101,722,458$ & $481,851,793$ \\
5 & Usaha & $2,535,411$ & $2,756,205$ & $2,674,671$ & $2,839,711$ & $2,891,224$ & $13,697,222$ \\
& Besar & & & & & & \\
& Total & $93,027,361$ & $96,780,483$ & $98,886,003$ & $102,241,486$ & $104,613,682$ & $495,549,015$ \\
\hline
\end{tabular}

Sources: Ministry of Cooperatives and Small and Medium Enterprises of the Republic of Indonesia

According to the Ministry of Cooperatives and Small and Medium Enterprises of the Republic of Indonesia, the number of UMKM business units has a fairly high increase each year, namely in 2010 amounting to 90,491,950 until 2014 amounting to 101,722,458, while for the large scale business industry only has a very slight increase from each. the year, namely in 2010 amounted to 2,535,411 until 2014 amounted to 2,891,224.

The comparison shown provides information to us that the MSMEs in Indonesia are the backbone of the national economy that must be maintained. MSMEs in Indonesia are one of the main players in domestic economic activities that support a large number of workers and an important source of income for low-income communities. This has resulted in the low competitiveness of Indonesian MSMEs from an international perspective. 


\section{FORMULATION OF THE PROBLEM}

Based on the background that has been explained, the research problems that will be studied can be formulated are:

1. How much influence does the value creation product strategy have on increasing business competitiveness as an effort to improve the economy of poor families

\section{Hypothesis}

$\mathrm{H}_{1}$ :There is a positive effect of value creation product strategy on increasing business competitiveness and its impact on improving the economy of poor families.

$\mathrm{H}_{0}$ : There is no positive effect of a value creation product strategy on increasing business competitiveness and its impact on improving the economy of poor families.

\section{LITERATURE REVIEW}

\section{Value Creation}

According Bowman \& Ambrosini, 2007; Ciasullo \& Troisi, 2013; Lautermann, 2013 , kreasi nilai adalah Penerapan strategi kreasi nilai dalam upaya perbaikan aktivitas usaha yang dilakukan sebagai strategi dalam level korporat maupun bisnis. Sedangkan menurut Tan Swee Lin \& Smyrnios, 2007, value creation is the application of a value creation strategy in an effort to improve business activities carried out as a strategy at the corporate and business levels. Meanwhile, according to Tan Swee Lin \& Smyrnios, 2007, value creation is a core element of entrepreneurship because innovative products / services that do not transmit market value lack commercial potential. Based on the previous definition, it can be concluded that value creation is very important to be owned by entrepreneurial businesses that are run so that MSMEs go through the implementation of innovative products.

According Orville C. Walker and John W. Mullins, 2014, Strategy is a basic pattern that is planned and has a purpose in the distribution of resources, and the organization's interaction with markets, competitors, and other environmental factors and how resources and activities that meet in the environment are able to generate opportunities and overcome challenges to gain profits for the company. The application of value creation that focuses on the internal resources owned is also related to the competitiveness strategy in an effort to increase the competitiveness of the company (Zubac, Hubbard, \& Johnson, 2010).

\section{Competitiveness}

According Luo, 2010 ,defines competitiveness as the degree to which a firm's products are deemed to have superior fitness to use, free from deficiencies, and conformity to requirements relative to competing firms. Meanwhile, according to Díaz-Chao, SainzGonzález, \& Torrent-Sellens, 2015 said that competitiveness is the ability to produce goods 
and services that meet customer needs, and at the same time maintain a high and sustainable income level, or the ability of a region to generate high levels of income and job opportunities by remaining open to external competition, it is also in accordance with the research conducted Pragya Bhawsar, Utpal Chattopadhyay, 2018 Competitiveness is an inclusive concept that combines all the factors that make an entity successful. So it can be concluded that competitiveness is the basic thing that companies must have in order to achieve success in the business world competition that companies must face.

\section{RESEARCH METHOD}

This research uses descriptive and verification research methods, so the method used is an explanatory survey. Data collection techniques are literature study and questionnaires (questionnaire). This research was conducted on business owners in Karawang Regency with a sample size of 100 respondents. This study used a cross sectional method which was conducted in less than one year. The data analysis technique used to determine the correlative relationship in this study is multiple regression using SPSS software.

\section{RESULT AND DISCUSSION}

Validity Test

Table 2

Validity Test Result

\begin{tabular}{llccc}
\hline & P & r count & r \\
table & Result \\
& \multicolumn{3}{c}{ Value Creation } \\
\hline 1 & P1 & 0,486 & 0,196 & Valid \\
2 & P2 & 0,618 & 0,196 & Valid \\
3 & P3 & 0,227 & 0,196 & Valid \\
4 & P4 & 0,654 & 0,196 & Valid \\
5 & P5 & 0,384 & 0,196 & Valid \\
6 & P6 & 0,532 & 0,196 & Valid \\
7 & P7 & 0,451 & 0,196 & Valid \\
8 & P8 & 0,312 & 0,196 & Valid \\
9 & P9 & 0,323 & 0,196 & Valid \\
10 & P10 & 0,661 & 0,196 & Valid \\
11 & P11 & 0,445 & 0,196 & Valid \\
12 & P12 & 0,407 & 0,196 & Valid \\
\hline
\end{tabular}




\begin{tabular}{|c|c|c|c|c|}
\hline 13 & P13 & 0,590 & 0,196 & Valid \\
\hline 14 & P14 & 0,394 & 0,196 & Valid \\
\hline 15 & P15 & 0,346 & 0,196 & Valid \\
\hline 16 & P16 & 0,428 & 0,196 & Valid \\
\hline 17 & P17 & 0,566 & 0,196 & Valid \\
\hline 18 & P18 & 0,431 & 0,196 & Valid \\
\hline 19 & P19 & 0,492 & 0,196 & Valid \\
\hline 20 & $\mathrm{P} 20$ & 0,312 & 0,196 & Valid \\
\hline 21 & $\mathrm{P} 21$ & 0,500 & 0,196 & Valid \\
\hline 22 & $\mathrm{P} 22$ & 0,454 & 0,196 & Valid \\
\hline \multirow[t]{2}{*}{23} & $\mathrm{P} 23$ & 0,408 & 0,196 & Valid \\
\hline & Com & & & \\
\hline 1 & $\mathrm{P} 1$ & 0,226 & 0,196 & Valid \\
\hline 2 & $\mathrm{P} 2$ & 0,507 & 0,196 & Valid \\
\hline 3 & P3 & 0,227 & 0,196 & Valid \\
\hline 4 & $\mathrm{P} 4$ & 0,442 & 0,196 & Valid \\
\hline 5 & P5 & 0,665 & 0,196 & Valid \\
\hline 6 & P6 & 0,527 & 0,196 & Valid \\
\hline 7 & P7 & 0,597 & 0,196 & Valid \\
\hline 8 & P8 & 0,582 & 0,196 & Valid \\
\hline 9 & P9 & 0,533 & 0,196 & Valid \\
\hline 10 & P10 & 0,446 & 0,196 & Valid \\
\hline 11 & P11 & 0,571 & 0,196 & Valid \\
\hline 12 & P12 & 0,397 & 0,196 & Valid \\
\hline 13 & P13 & 0,426 & 0,196 & Valid \\
\hline 14 & P14 & 0,665 & 0,196 & Valid \\
\hline 15 & P15 & 0,503 & 0,196 & Valid \\
\hline 16 & P16 & 0,210 & 0,196 & Valid \\
\hline 17 & P17 & 0,550 & 0,196 & Valid \\
\hline 18 & P18 & 0,385 & 0,196 & Valid \\
\hline 19 & P19 & 0,280 & 0,196 & Valid \\
\hline 20 & P20 & 0,577 & 0,196 & Valid \\
\hline
\end{tabular}




\begin{tabular}{lllll}
\hline 21 & P21 & 0,351 & 0,196 & Valid \\
22 & P22 & 0,329 & 0,196 & Valid \\
\hline
\end{tabular}

Sources: Data Processing, 2019

Table 1 on the variable instrument of value creation and competitiveness shows that all question items are declared valid.

\section{Reliability Test}

Tabel 3

Reliability Test Result

\begin{tabular}{ccccc}
\hline No & Variabel & r count & r & Result \\
& & & table & \\
\hline 1 & Value Creation & 0,782 & 0,6 & Reliable \\
& $(\mathrm{X})$ & & & \\
2 & Competitiveness & 0,800 & 0,6 & Reliable \\
& $(\mathrm{Y})$ & & & \\
\hline
\end{tabular}

Sources: Data Processing, 2019

Table 3 shows that the two variables examined in this study are reliable, which means that the measuring instrument in this study is a consistent and reliable measuring tool.

\section{Linearity Test}

Tabel 4

Linearity Test

\begin{tabular}{llrr}
\multicolumn{4}{c}{ Linearity Test } \\
\hline & \multicolumn{1}{c}{ Correlations } \\
& & $\begin{array}{c}\text { Value } \\
\text { Creation }\end{array}$ & Competitiveness \\
& & 1 &, $319^{* *}$ \\
Value & Pearson & &, 001 \\
Creation & Correlation & & 100 \\
& Sig. (2-tailed) & & 1 \\
& N & 100 & \\
Daya Saing & Pearson &, $319^{* *}$ & \\
& Correlation & & \\
& Sig. (2-tailed) &, 001 & \\
\hline
\end{tabular}




\begin{tabular}{lrr}
\hline $\mathrm{N}$ & 100 & 100 \\
\hline
\end{tabular}

Sources: Data Processing, 2019

Based on Table 4 the SPSS output, the correlation between the explanatory variable and the response variable, $\mathrm{P}$-value $0.000<0.05$. so that the decision to reject $\mathrm{H} 0$, meaning that the explanatory variable has a real linear relationship (correlation) to the response variable.

\section{Heteroscedasticity Test}

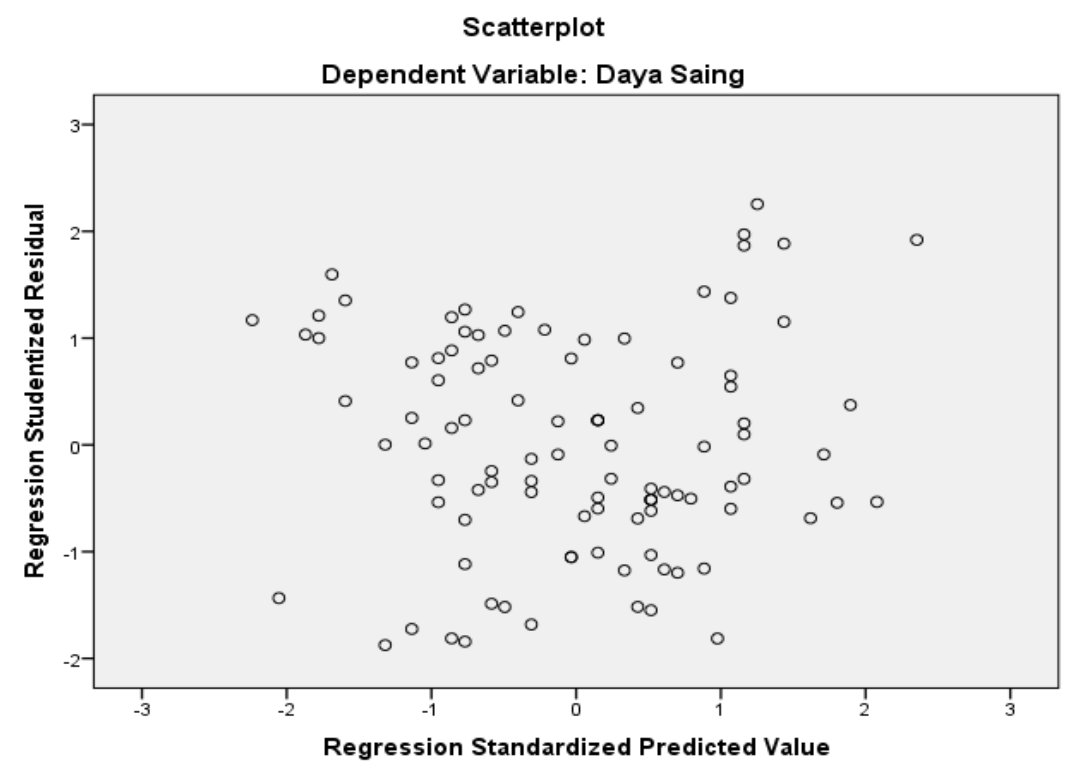

Sources: Data Processing, 2019

Picture 1

Heteroscedasticity Test result

Based on Figure 1 shows no clear pattern and the dots are spreading. It can be concluded that there is no heteroscedasticity in the regression model, so the regression model is suitable to be used to predict the effect of value creation on competitiveness.

\section{Normality Test}

Tabel 5

Normality Test Result

Tests of Normality

Kolmogorov- Shapiro-Wilk

Smirnov $^{\mathrm{a}}$ 


\begin{tabular}{lcrrrrr} 
& $\begin{array}{c}\text { Statisti } \\
\text { c }\end{array}$ & df & Sig. & $\begin{array}{r}\text { Statisti } \\
\text { c }\end{array}$ & Df & Sig. \\
\hline Value & .071 & 100 & .200 & .989 & 100 & .566 \\
Creation & & & $*$ & & & \\
Competitivene & .082 & 100 & .095 & .976 & 100 & .065 \\
ss & & & & & & \\
\hline
\end{tabular}

Sources: Data Processing, 2019

Based on the normality test above, it is known that the Kolmogorov-Smirnov table obtained a sig value for variable $X$ (value creation) of 0.200 where $0.200>0.05$ and for variable Y (Competitiveness) obtained a sig value of 0.095 where $0.095>0.05$, which means normally distributed data.

\section{Regresission Test}

\section{Coefficient of Determination}

Tabel 6

Coefficient of Determination Result

\begin{tabular}{|c|c|c|c|c|c|c|}
\hline \multirow{3}{*}{ Model } & \multicolumn{5}{|c|}{ Model Summary $^{b}$} & \\
\hline & \multirow[t]{4}{*}{$\mathrm{R}$} & \multirow{4}{*}{$\begin{array}{c}\mathrm{R} \\
\text { Square }\end{array}$} & \multirow{4}{*}{$\begin{array}{l}\text { Adjusted } \\
\text { R Square }\end{array}$} & \multirow{4}{*}{$\begin{array}{c}\text { Std. Error } \\
\text { of the } \\
\text { Estimate }\end{array}$} & Change Statistics & \\
\hline & & & & & $\mathrm{R}$ & $\mathrm{F}$ \\
\hline & & & & & Square & Change \\
\hline & & & & & \multicolumn{2}{|l|}{ Change } \\
\hline 1 &, $319^{\mathrm{a}}$ & ,102 & ,093 & 9,725 & ,102 & 11,122 \\
\hline
\end{tabular}

Sources: Data Processing, 2019

Based on Table 1, it is found that the R Square value is 0.102 , which means that there is an influence of Value Creation (X1) of $10.2 \%$ on Competitiveness (Y), while the remaining $89.8 \%$ is influenced by other factors.

\section{Autocorrelation Test}

Tabel 7

Autocorrelation Test Result

\begin{tabular}{ccccc}
\hline \multirow{4}{*}{ Model Summary } \\
Model & \multicolumn{3}{c}{ Change Statistics } & Durbin- \\
& df1 & df2 & Sig. F & Watson \\
& & \multicolumn{3}{c}{ Change } \\
\hline
\end{tabular}




\begin{tabular}{ccccc}
\hline 1 & $1^{\text {a }}$ & 98 &, 001 & 1,130 \\
\hline \multicolumn{3}{l}{ Sources: Data Processing, 2019}
\end{tabular}

There are Durbin-Watson table values as follows:

$$
\begin{aligned}
& \mathrm{dL}=1,6504 \\
& \mathrm{dU}=1,6916
\end{aligned}
$$

Based on Table 2 shows that the Durbin-Watson value is 1.130 , so DW <dL or DW $>$ dU. This means that there is positive autocorrelation.

\section{Simultaneous Hypothesis Testing (F Test)}

Table 8

F Test

ANOVA $^{\mathrm{a}}$

\begin{tabular}{llcrccc}
\hline Model & $\begin{array}{l}\text { Sum of } \\
\text { Squares }\end{array}$ & Df & $\begin{array}{c}\text { Mean } \\
\text { Square }\end{array}$ & F & Sig. \\
& \multicolumn{1}{c}{ Regression } & 1051,831 & 1 & 1051,831 & 11,122 &, $001^{\mathrm{b}}$ \\
\multirow{2}{*}{1} & Residual & 9268,329 & 98 & 94,575 & & \\
& Total & 10320,160 & 99 & & & \\
\hline
\end{tabular}

Sources: Data Processing, 2019

Based on Table 3, it is found that F count is 11,122> F table, namely F (1.98) of 3.94 then $\mathrm{Ho}$ is rejected and $\mathrm{Ha}$ is accepted, meaning that Value Creation (X1) affects Competitiveness (Y). And based on the significance value (Sig) is equal to 0.001 where $0.001<0.05$, which means that there is a significant relationship between Value Creation (X1) and Competitiveness (Y).

\section{Partial Hypothesis Test (T Test)}

Tabel 9

T Test

\section{Coefficients $^{\mathrm{a}}$}

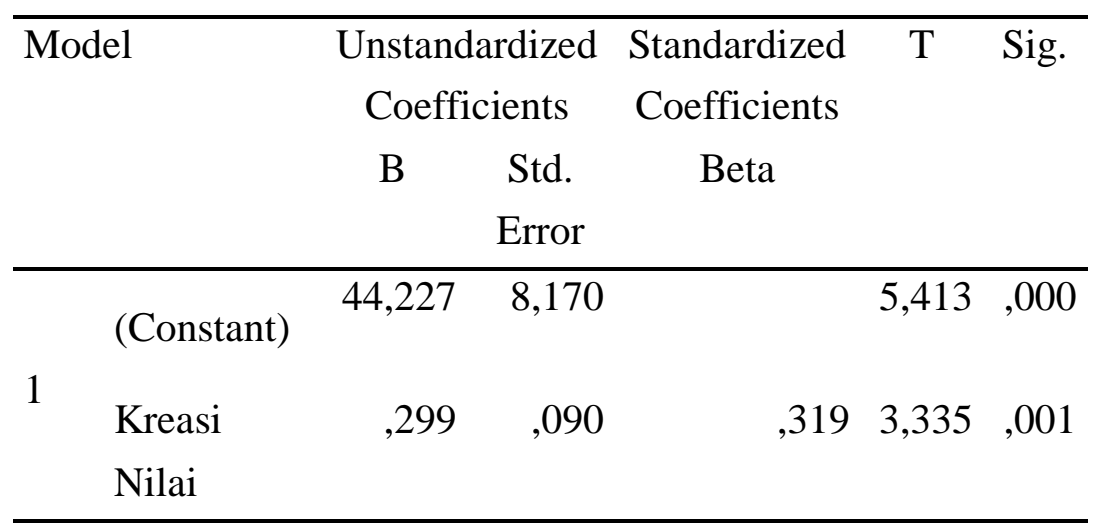

Sources: Data Processing, 2019 
Based on Table 4, it is obtained that the value of a (constant number) is 44.227 and the value of $b$ (regression coefficient) is 0.299 , then the regression equation is:

$\mathrm{Y}=\mathrm{a}+\mathrm{bX}$

$\mathrm{Y}=44,227+0,299 \mathrm{X}$

This shows that,

1. Competitiveness $=44.227$, which means that if there is no Value Creation (X1) then the consistent value for Competitiveness (Y) is 44.227.

2. The regression coefficient is 0.299 , which means that every $1 \%$ addition of Value Creation (X1) increases the Competitiveness (Y) of 0.299.

Based on the $t$ value in the Coefficients Table, it is found that $t$ count is 3,335> $t$ table (with a significance level $=0.05$ ) which is 1.98447 , so Ho is rejected and Ha is accepted, meaning that there is an influence between Value Creation (X1) on Competitiveness (Y). And based on the significance value (Sig) is equal to 0.001 where $0.001<0.05$, which means that there is a significant relationship between Value Creation (X1) and Competitiveness (Y). The results of this study support previous research conducted by (Çapraz \& Tutan, 2013; Sánchez-Gutiérrez, Cabanelas, Lampón, \& González-Alvarado, 2019) which shows that the creation of value creation in corporate strategy has a positive and significant effect on competitiveness, where the results of the study explain when relationship management capabilities are taken together with increased marketing and innovation, thus having a higher level of competitiveness.

\section{CONCLUSION}

Based on the results of the research that has been done, the results of the study can be concluded that there is a positive effect of value creation product strategy on increasing business competitiveness as an effort to improve the economy of poor families..

\section{THANK-YOU NOTE}

Researchers are grateful for the completion of this research, and researchers would like to thank all those who have helped and participated in this research so that it was carried out well and successfully.

\section{REFERENCES}

Bowman, C., \& Ambrosini, V. (2007). Firm value creation and levels of strategy. Management Decision, 45(3), 360-371. https://doi.org/10.1108/00251740710745007

Çapraz, B., \& Tutan, M. U. (2013). The Linkage between Competitive Factors and Value Creation in Local Trade Centers. Procedia - Social and Behavioral Sciences, 99, 648- 
657. https://doi.org/10.1016/j.sbspro.2013.10.535

Ciasullo, M. V., \& Troisi, O. (2013). Sustainable value creation in SMEs: A case study. TQM Journal, 25(1), 44-61. https://doi.org/10.1108/17542731311286423

Crick, D., Kaganda, G. E., \& Matlay, H. (2011). A study into the international competitiveness of low and high intensity Tanzanian exporting SMEs. Journal of Small Business and Enterprise Development, 18(3), 594-607. https://doi.org/10.1108/14626001111155727

Díaz-Chao, Á., Sainz-González, J., \& Torrent-Sellens, J. (2015). ICT, innovation, and firm productivity: New evidence from small local firms. Journal of Business Research, 68(7), 1439-1444. https://doi.org/10.1016/j.jbusres.2015.01.030

Gilmore, A. (2011). Entrepreneurial and SME marketing. Journal of Research in Marketing and Entrepreneurship, 13(2), 137-145. https://doi.org/10.1108/14715201111176426

Lautermann, C. (2013). The ambiguities of (social) value creation: towards an extended understanding of entrepreneurial value creation for society. Social Enterprise Journal, 9(2), 184-202. https://doi.org/10.1108/sej-01-2013-0009

Luo, X. (2010). Product competitiveness and beating analyst earnings target. Journal of the Academy of Marketing Science, 38(3), 253-264. https://doi.org/10.1007/s11747-0090158-9

merdeka.com. (n.d.). BPS: 10,25 Persen Warga Karawang Hidup Miskin | merdeka.com. Retrieved November 30, 2019, from https://www.merdeka.com/peristiwa/bps-1025warga-karawang-hidup-miskin.html

Najib, M., \& Kiminami, A. (2011). Innovation, cooperation and business performance: Some evidence from Indonesian small food processing cluster. Journal of Agribusiness in Developing and Emerging Economies, 1(1), 75-96. https://doi.org/10.1108/20440831111131523

Orville C. Walker and John W. Mullins, 2014. (2014). Marketing strategy: a decisionfocused approach. 8th edition. 1221 Avenue of the Americas, New York, NY10020: McGraw-Hill.

Pragya Bhawsar, Utpal Chattopadhyay, A. (2018). Evaluation of industry cluster competitiveness: a quantitative approach. Benchmarking: An International Journal, $34(1), 1-5$.

Sánchez-Gutiérrez, J., Cabanelas, P., Lampón, J. F., \& González-Alvarado, T. E. (2019). The impact on competitiveness of customer value creation through relationship capabilities and marketing innovation. Journal of Business and Industrial Marketing, 
34(3), 618-627. https://doi.org/10.1108/JBIM-03-2017-0081

Sultan, S. S. (2014). Enhancing the competitiveness of palestinian SMEs through clustering. EuroMed Journal of Business, 9(2), 164-174. https://doi.org/10.1108/EMJB-03-20120004

Tambunan, T. T. H. (2011). Development of micro, small and medium enterprises and their constraints: A story from Indonesia. Gadjah Mada International Journal of Business, 13(1), 21-43. https://doi.org/10.22146/gamaijb.5492

Tan Swee Lin, C., \& Smyrnios, K. X. (2007). Customer-Value Based Marketing Activities in Fast-Growth Firms. Journal of Research in Marketing and Entrepreneurship. https://doi.org/10.1108/14715200780001340

Valkokari, K., \& Helander, N. (2007). Knowledge management in different types of strategic SME networks. Management Research News, 30(8), 597-608. https://doi.org/10.1108/01409170710773724

Zubac, A., Hubbard, G., \& Johnson, L. W. (2010). The RBV and value creation: a managerial perspective. https://doi.org/10.1108/09555341011068921 